\title{
66 kDa Phosphoprotein Antibody Positive
}

National Cancer Institute

\section{Source}

National Cancer Institute. 66 kDa Phosphoprotein Antibody Positive. NCI Thesaurus.

Code C141280.

An indication that antibodies that recognize the CMV 65 kDa phosphoprotein have been detected in a sample. 